\section{PkM UJI KOMPETENSI \\ KEAHLIAN SISWA \\ JURUSAN TEKNIK \\ OTOMOTIF ALAT BERAT \\ DI SMK RIGOMASI BONTANG}

\author{
Ahmad Yani' \\ 'Sekolah Tinggi Teknologi Industri \\ Bontang - KALTIM \\ *Ahmad Yani \\ Email: yanibima@gmail.com
}

\begin{abstract}
Expertise Competency Test (UKK) is part of government intervention in ensuring the quality of education in Vocational High School education units. One of the government's efforts to improve students' knowledge and skills, especially for Vocational High Schools, is by holding a skill competency test that determines student graduation. Competency testing is needed to determine a person's ability or competence according to professional standards. To be accepted to work in the world of work, a person must be competent, which is evidenced by, among other things, a competency certificate through a competency test. A person is said to have the competence (competent) in a particular field if he has the knowledge, skills, and attitudes to complete the job correctly by the demands of professionalism. The purpose of implementing this UKK is to measure the competency attainment of Rigomasi Vocational High School students at a certain level according to the expertise of heavy equipment automation engineering majors taken during the learning period at school.
\end{abstract}

Keywords: UKK, Students, Vocational High School, Automotive Engineering.

\begin{abstract}
Abstrak
Uji Kompetensi Keahlian (UKK) merupakan bagian dari intervensi pemerintah dalam menjamin mutu pendidikan pada satuan pendidikan Sekolah Menengah Kejuruan. Salah satu upaya pemerintah dalam meningkatkan pengetahuan dan keterampilan siswa khususnya untuk Sekolah Menengah Kejuruan yaitu dengan menyelenggarakan ujian kompetensi keahlian yang menjadi penentu bagi kelulusan siswa. Uji kompetensi diperlukan untuk mengetahui kemampuan atau kompetensi seseorang sesuai dengan standar profesi, karena untuk dapat diterima bekerja di dunia kerja seseorang harus kompeten yang antara lain dibuktikan dengan sertifikat kompetensi melalui uji kompetensi. Seseorang dikatakan memiliki kompetensi (berkompeten) dalam bidang tertentu, apabila dia memiliki pengetahuan, keterampilan, dan sikap untuk menyelesaikan pekerjaan tersebut dengan baik sesuai dengan tuntutan profesionalisme. Tujuan dari pelaksanaan UKK ini yaitu untuk mengukur pencapaian kompetensi siswa SMK Rigomasi pada level tertentu sesuai kompetensi keahlian jurusan teknik otomatif alat berat yang ditempuh selama masa pembelajaran di sekolah.
\end{abstract}

Kata kunci: UKK, Siswa, SMK, Teknik Otomotif. 
PkM Uji Kompetensi Keahlian Siswa Jurusan Teknik Otomotif Alat Berat di SMK Rigomasi Bontang

Ahmad Yani

Volume 1, No. 3, Desember 2021 hal. 259-272

DOI Artikel: 10.46306/jub.v1i3.49

\section{PENDAHULUAN}

Sekolah Menengah Kejuruan (SMK) Rigomasi Bontang merupakan SMK pertama di Kota Bontang yang berdiri pada Tahun 1987, dengan seiringnya waktu hingga saat ini terdapat empat kompetensi keahlian yang menjadi produk unggulan sekolah, baik dari penyediaan tenaga kerja maupun pelayanan publik diantaranya Teknik Alat Berat, Teknik Kendaraan Ringan, Teknik Instalasi Tenaga Listrik, dan Teknik Komputer Jaringan (Yani et al, 2020).

Uji Kompetensi Keahlian adalah bagian dari intervensi pemerintah dalam menjamin mutu pendidikan pada satuan pendidikan SMK (Yani et al, 2020). Salah satu upaya pemerintah dalam meningkatkan pengetahuan dan keterampilan siswa SMK yaitu dengan menyelenggarakan ujian kompetensi keahlian yang menjadi penentu bagi kelulusan siswa (Hamidah et al, 202I). Kegiatan UKK merupakan sebuah aktivitas pendidikan yang sangat strategis untuk mengungkap capaian kompetensi siswa (Saptono et al., 2020). Pelaksanaan UKK bertujuan untuk mengukur pencapaian kompetensi siswa pada level tertentu sesuai kompetensi keahlian yang ditempuh selama masa pembelajaran di SMK (Putri et al, 2017). Uji kompetensi digunakan untuk mengukur kemampuan kognitif siswa dengan menggunakan format penilaian tes praktikum atau pengamatan kegiatan terhadap kelompok atau individu (Suratno, 2016). Kompetensi adalah suatu kemampuan untuk melaksanakan atau melakukan suatu pekerjaan atau tugas yang dilandasi atas keterampilan dan pengetahuan serta didukung oleh sikap kerja yang dituntut oleh pekerjaan tersebut (Purnama \& Awalin, 2020).

Pada pelaksanaan uji kompetensi guru dan Dunia Usaha/Dunia Industri (DU/DI) sangat berperan penting dalam penilaian kompetensi yang dimiliki siswa (Irwanti, 20/4). Dalam penilaian uji kompetensi guru merupakan asesor internal yang harus memenuhi kriteria yang telah ditetapkan, sedangkan DU/DI atau pihak universitas berfungsi sebagai asesor eksternal yang harus memenuhi kriteria yang telah ditetapkan dan mempunyai kompetensi sesuai bidang yang diujikan. Dalam konteks pendidikan, asesmen atau penilaian merupakan suatu kegiatan untuk mengetahui perkembangan, kemajuan dan hasil belajar siswa. Menurut Wagiran (20II) bahwa penilaian merupakan upaya sistematis yang dikembangkan oleh suatu institusi pendidikan yang ditujukan untuk menjamin tercapainya kualitas proses pendidikan serta kualitas kemampuan peserta didik sesuai dengan tujuan yang telah ditetapkan.

Indikator keberhasilan dalam melakukan uji kompetensi keahlian tidak hanya dilihat dari penilaian siswa saja, akan tetapi yang lebih penting adalah kerjasama yang terjalin secara terus menerus antara sekolah mitra dengan pihak universitas (Putra et al. 2020). Tridharma Perguruan Tinggi adalah Pendidikan, Penelitian, dan Pengabdian Masyarakat (Yani et al, 202I). Pengabdian Masyarakat merupakan salah satu dari Tridharma Perguruan Tinggi yang wajib dilakukan oleh dosen sebagai bentuk kepedulian institusi perguruan tinggi yang bergerak dibidang Pendidikan (Yani et al, 2020).

Uji kompetensi diperlukan untuk mengetahui kemampuan atau kompetensi seseorang sesuai dengan standar profesi (Ratnawati, 202I). Untuk dapat diterima bekerja di dunia kerja seseorang harus 
PkM Uji Kompetensi Keahlian Siswa Jurusan Teknik Otomotif Alat Berat di SMK Rigomasi Bontang Ahmad Yani

Volume 1, No. 3, Desember 2021 hal. 259-272

DOI Artikel: 10.46306/jub.v1i3.49

kompeten yang dibuktikan dengan sertifikat kompetensi melalui uji kompetensi. Seseorang dikatakan memiliki kompetensi (berkompeten) dalam bidang tertentu, apabila dia memiliki pengetahuan, keterampilan, dan sikap untuk menyelesaikan pekerjaan tersebut dengan baik sesuai dengan tuntutan profesionalisme. Tujuan dari pelaksanaan UKK ini yaitu untuk mengukur pencapaian kompetensi siswa SMK Rigomasi pada level tertentu sesuai kompetensi keahlian jurusan teknik otomatif alat berat yang ditempuh selama masa pembelajaran di sekolah.

\section{METODE PENGABDIAN}

\section{Lokasi Kegiatan}

Pengabdian masyarakat ini dilaksanakan di SMK Rigomasi Bontang Jalan A.Yani No. I Kelurahan Api-api - Kecamatan Bontang Utara - Kota Bontang - Kalimantan Timur. Kegiatan uji kompotensi ini dilaksanakan pada tanggal 5-7 April 202I.

\section{Metode Pelaksanaan}

Pelaksanaan kegiatan UKK dilakukan terdiri dari penilaian aspek pengetahuan dan penilaian aspek keterampilan.

Adapun penilaian aspek pengetahuan dalam pelaksanaan UKK ini sebagai berikut:

I. Memahami fungsi dan prinsip kerja Special tools

2. Memahami Safety di area kerja

3. Mengetahui Fungsi dan prinsip kerja system unit machine/ Engine

4. Memahami fungsi cylinder head

5. Menjelaskan cara kerja cylinder head

6. Memahami fungsi Diesel Fuel Injection Pump

7. Memahami cara kerja Diesel Fuel Injection Pump

8. Memahami fungsi komponen Radiator assy

9. Memahami cara kerja komponen Radiator assy

10. Menjelaskan perawatan machine 500 jam operasi sesuai dengan buku informasi SOP machine yang dirawat

II. Menjelaskan prosedur perawatan harian sesuai dengan buku Informasi perawatan harian model unit yang dirawat.

Sedangkan penilaian aspek keterampilan dalam pelaksanaan UKK ini sebagai berikut:

I. Persiapan

a. Menyiapkan perlengkapan keselamatan kerja dan Alat Pelindung Diri

b. Mempersiapkan alat yang diperlukan

c. Mencari data dari service manual

d. Melakukan pemeriksaan awal 
PkM Uji Kompetensi Keahlian Siswa Jurusan Teknik Otomotif Alat Berat di SMK Rigomasi Bontang Ahmad Yani

Volume 1, No. 3, Desember 2021 hal. 259-272

DOI Artikel: 10.46306/jub.v1i3.49

2. Pelaksanaan
a. Melepas dan Memasang Cylinder Head Group
b. Melepas dan Memasang Fuel Injection Pump
c. Melepas dan Memasang Radiator Assy
d. Melepas dan Memasang Engine
e. Melepas dan Memasang Engine Brake
f. Merawat Unit Machine 500 Jam Operasi
g. Merawat Unit/Machine Harian/Daily Check (On Road)

3. Hasil Pelaksanaan
a. Hasil Melepas dan Memasang Cylinder Head Group
b. Hasil Melepas dan Memasang Fuel Injection Pump
c. Hasil Melepas dan Memasang Radiator Assy
d. Hasil Melepas dan Memasang Engine
e. Hasil Melepas dan Memasang Engine Brake
f. Hasil Merawat Unit Machine 500 Jam Operasi
g. Hasil Merawat Unit/Machine Harian/Daily Check

\section{PELAKSANAAN DAN PEMBAHASAN}

Kegiatan pengabdian masyarakat ini merupakan uji kompetensi harus menghadirkan pendamping yang berasal dari industri atau perguruan tinggi sebagai asesor uji kompetensi keahlian. Teknis pelaksanaan uji kompetensi dikoordinir pihak SMK Rigomasi dan Lembaga Penelitian dan Pengbdian kepada Masyarakat (LPPM) STTI Bontang dengan dukungan sumber daya manusia yang memiliki latar belakang keilmuan dibidang teknik mesin yang profesional dan berpengalaman dalam pelaksanaan kegiatan pendidikan dan pelatihan.

\section{Pelaksanaan}

Pada pelaksanaan uji kompetensi guru merupakan asesor internal yang harus memenuhi kriteria yang telah ditetapkan, sedangkan dosen teknik mesin Sekolah Tinggi Teknologi Industri Bontang berfungsi sebagai asesor eksternal yang harus memenuhi kriteria yang telah ditetapkan dan mempunyai kompetensi sesuai bidang yang diujikan. Dalam konteks pendidikan, asesmen atau penilaian merupakan suatu kegiatan untuk mengetahui perkembangan, kemajuan dan hasil belajar siswa. Dokumentasi interaksi asesor dengan siswa SMK Rigomasi dalam pelaksanaan UKK Tahun 202I dimasa Pandemi Covid 19 seperti ditunjukkan gambar I sampai gambar 8 berikut ini. 
PkM Uji Kompetensi Keahlian Siswa Jurusan Teknik Otomotif Alat Berat di SMK Rigomasi Bontang Ahmad Yani

Volume 1, No. 3, Desember 2021 hal. 259-272

DOI Artikel: 10.46306/jub.v1i3.49

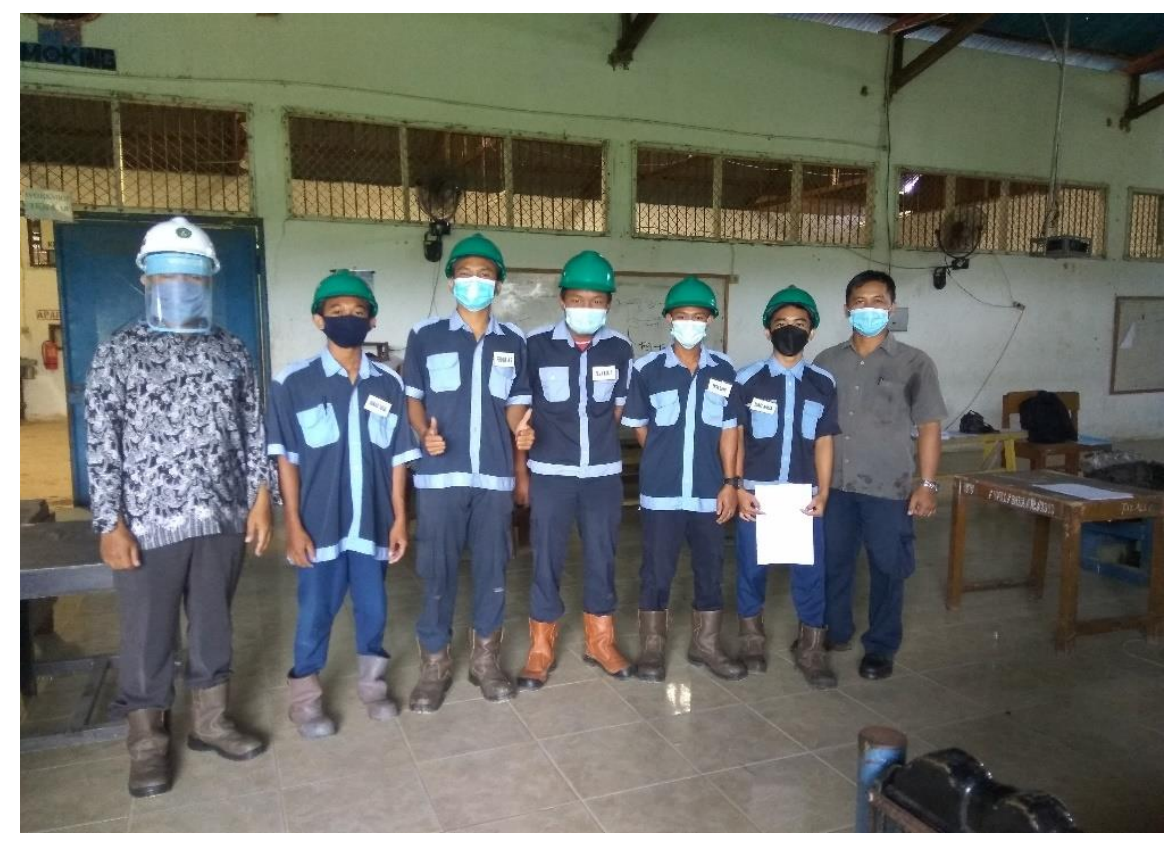

Gambar I. Foto bersama dengan siswa sebelum mulai UKK

Sumber. Dokumentasi tim lapangan

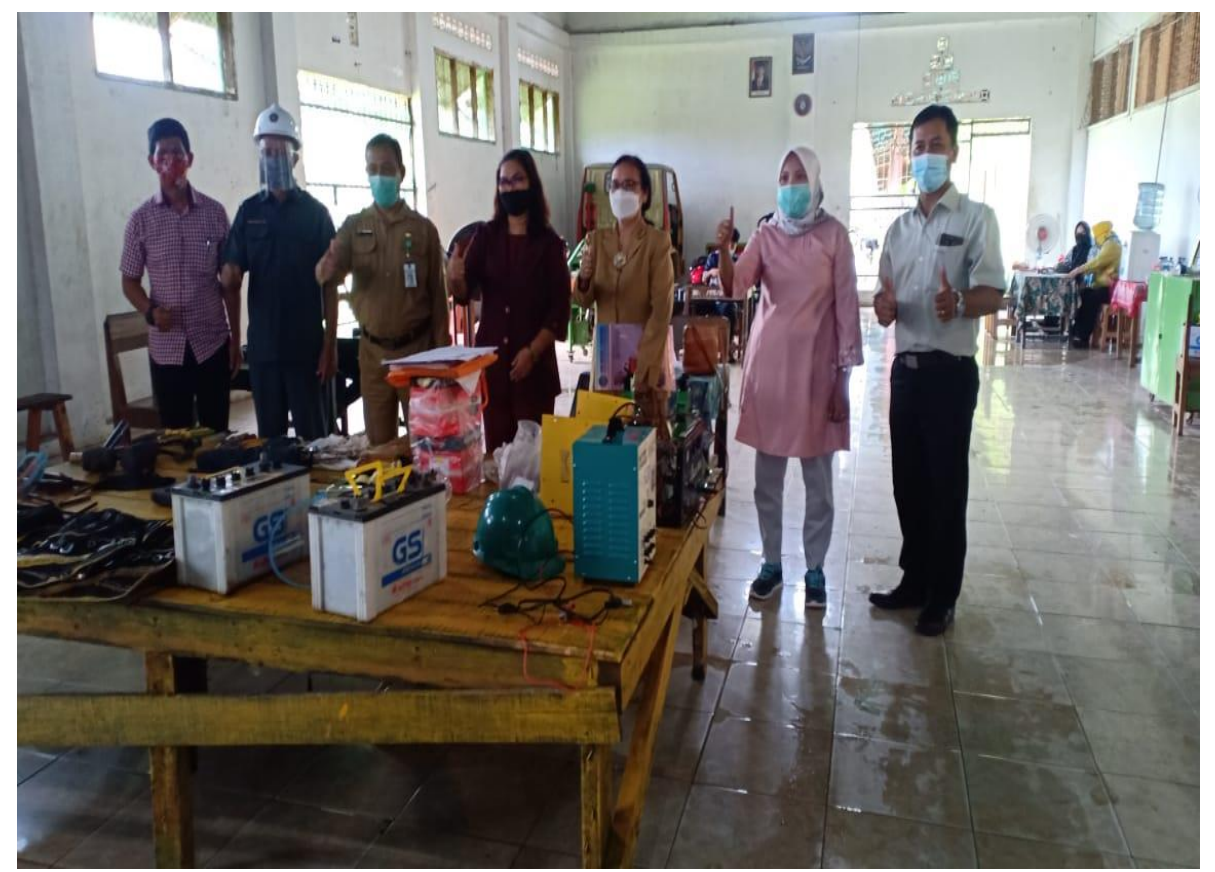

Gambar 2. Foto bersama dengan kepala sekolah, pengawas kota Bontang dan Provinsi KALTIM Sumber. Dokumentasi tim lapangan 
PkM Uji Kompetensi Keahlian Siswa Jurusan Teknik Otomotif Alat Berat di SMK Rigomasi Bontang Ahmad Yani

Volume 1, No. 3, Desember 2021 hal. 259-272

DOI Artikel: 10.46306/jub.v1i3.49

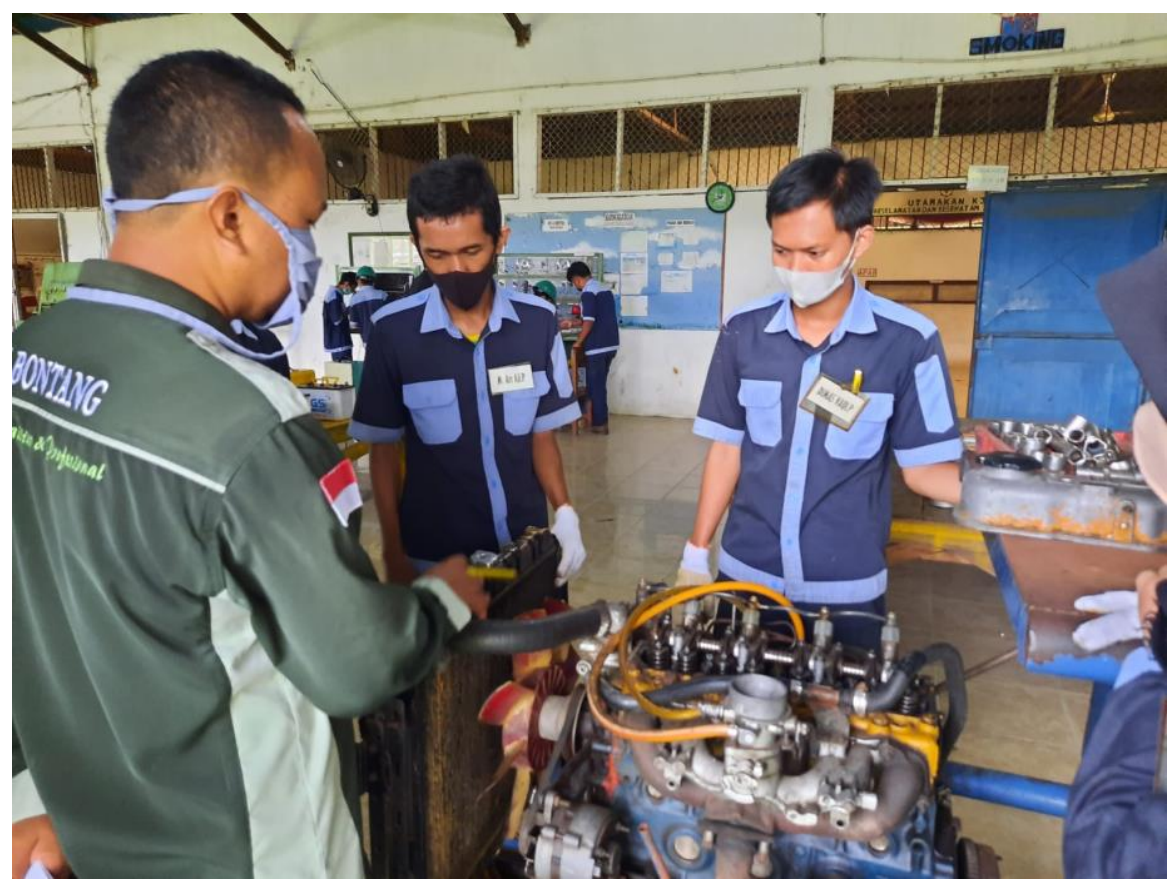

Gambar 3. Tanya jawab dengan siswa

Sumber. Dokumentasi tim lapangan

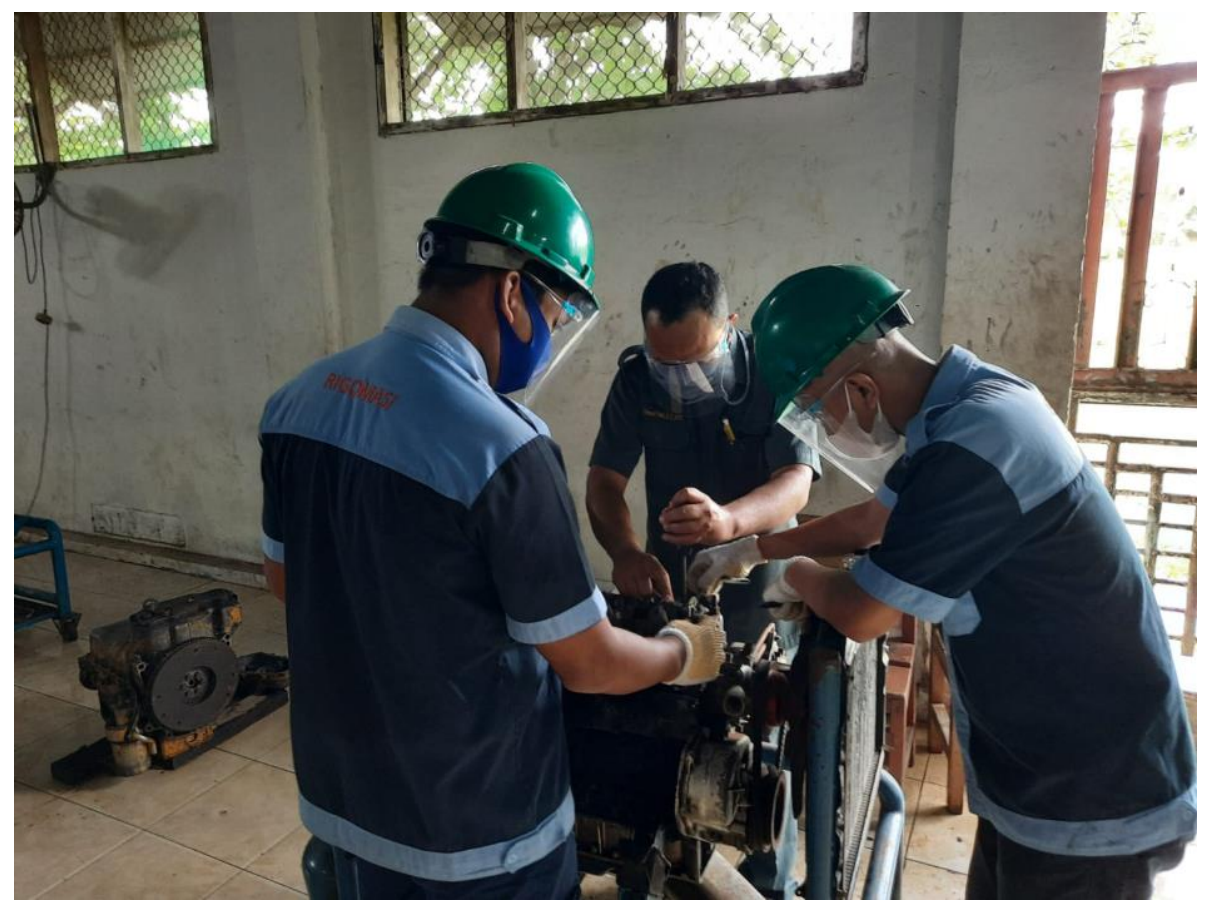

Gambar 4. Menunjukkan kepada siswa cara penyetelan katub yang benar Sumber. Dokumentasi tim lapangan 
PkM Uji Kompetensi Keahlian Siswa Jurusan Teknik Otomotif Alat Berat di SMK Rigomasi Bontang Ahmad Yani

Volume 1, No. 3, Desember 2021 hal. 259-272

DOI Artikel: 10.46306/jub.v1i3.49

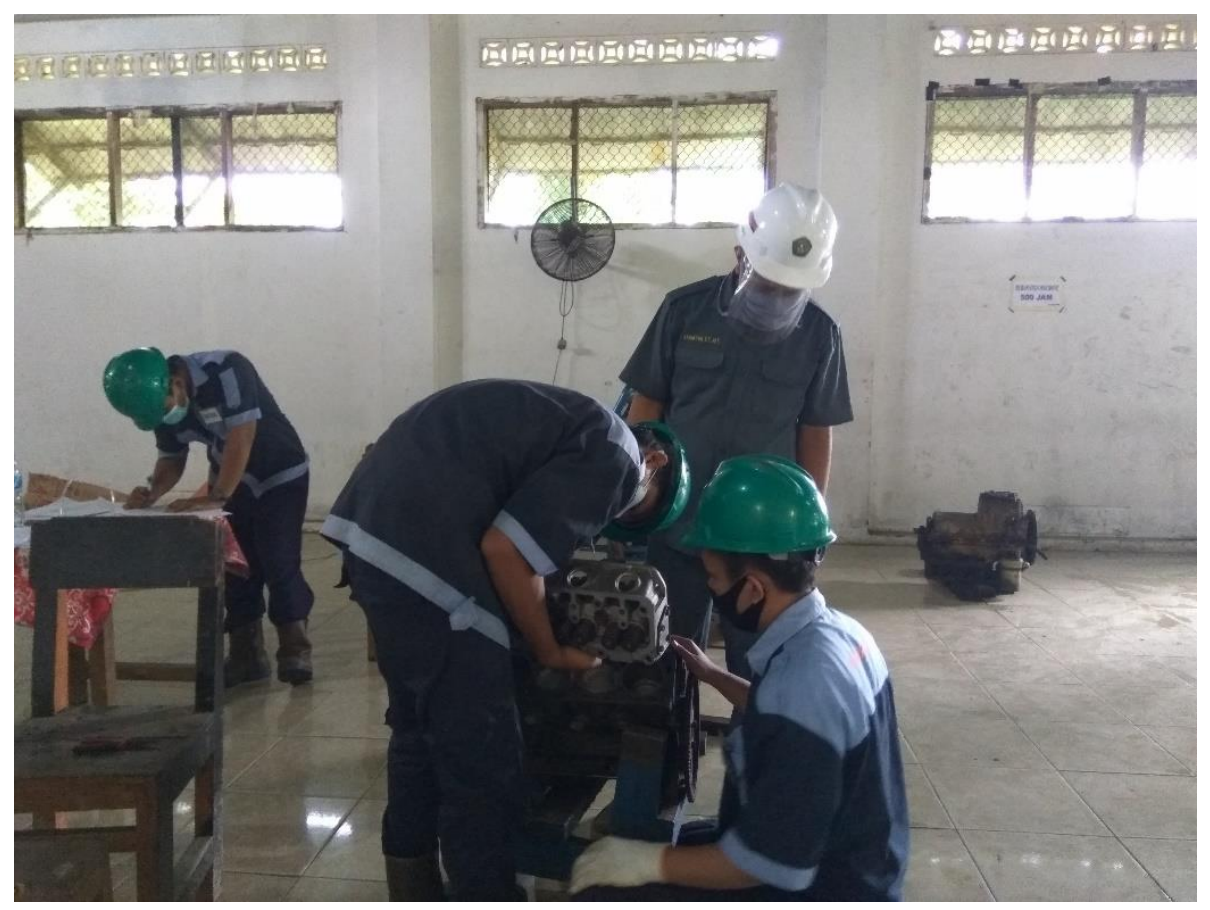

Gambar 5. Mengamati siswa yang membongkar silinder head Sumber. Dokumentasi tim lapangan

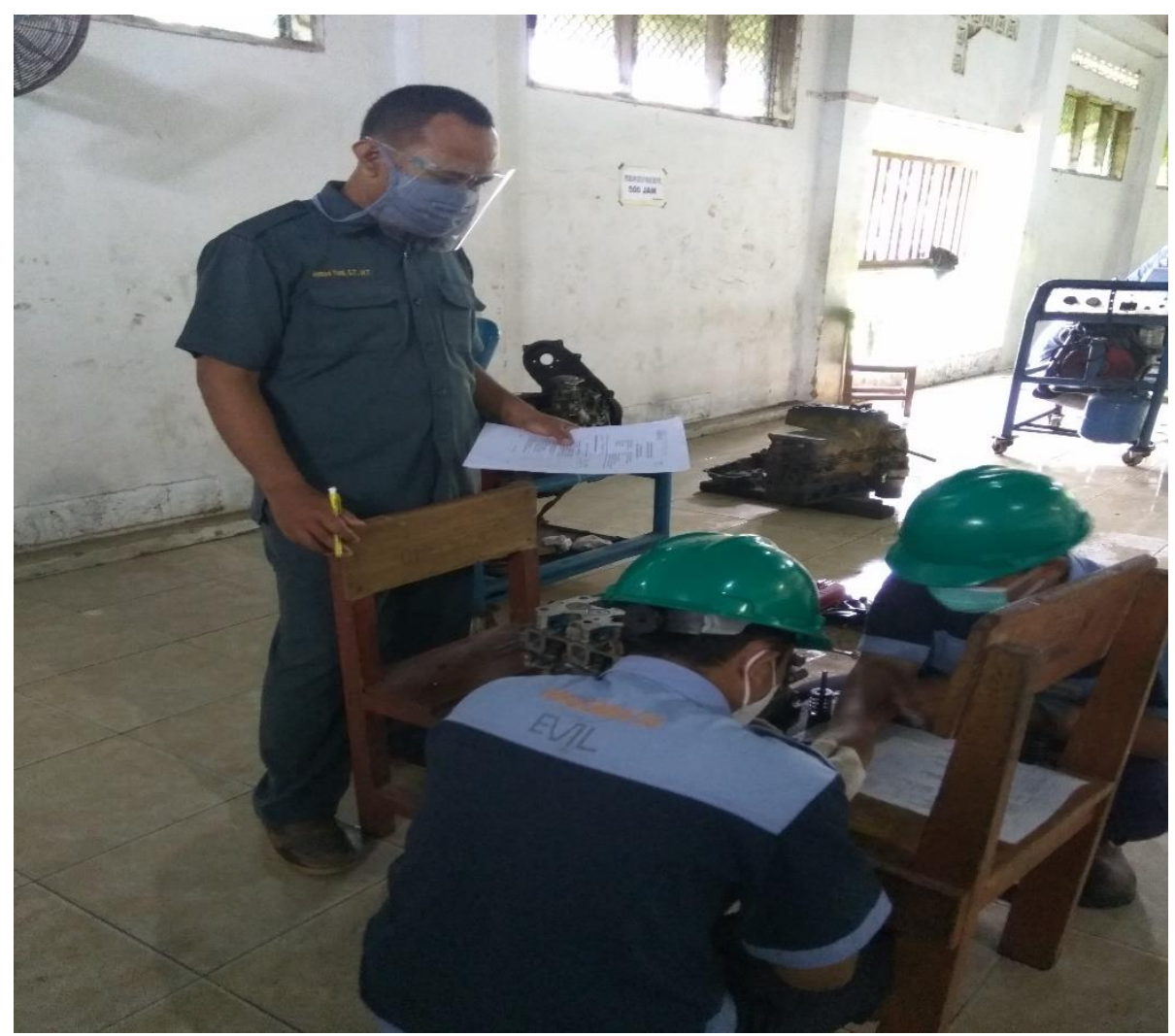

Gambar 6. Mengamati hasil kerja siswa yang sedang melakukan pengukuran komponen mesin Sumber. Dokumentasi tim lapangan 
PkM Uji Kompetensi Keahlian Siswa Jurusan Teknik Otomotif Alat Berat di SMK Rigomasi Bontang Ahmad Yani

Volume 1, No. 3, Desember 2021 hal. 259-272

DOI Artikel: 10.46306/jub.v1i3.49

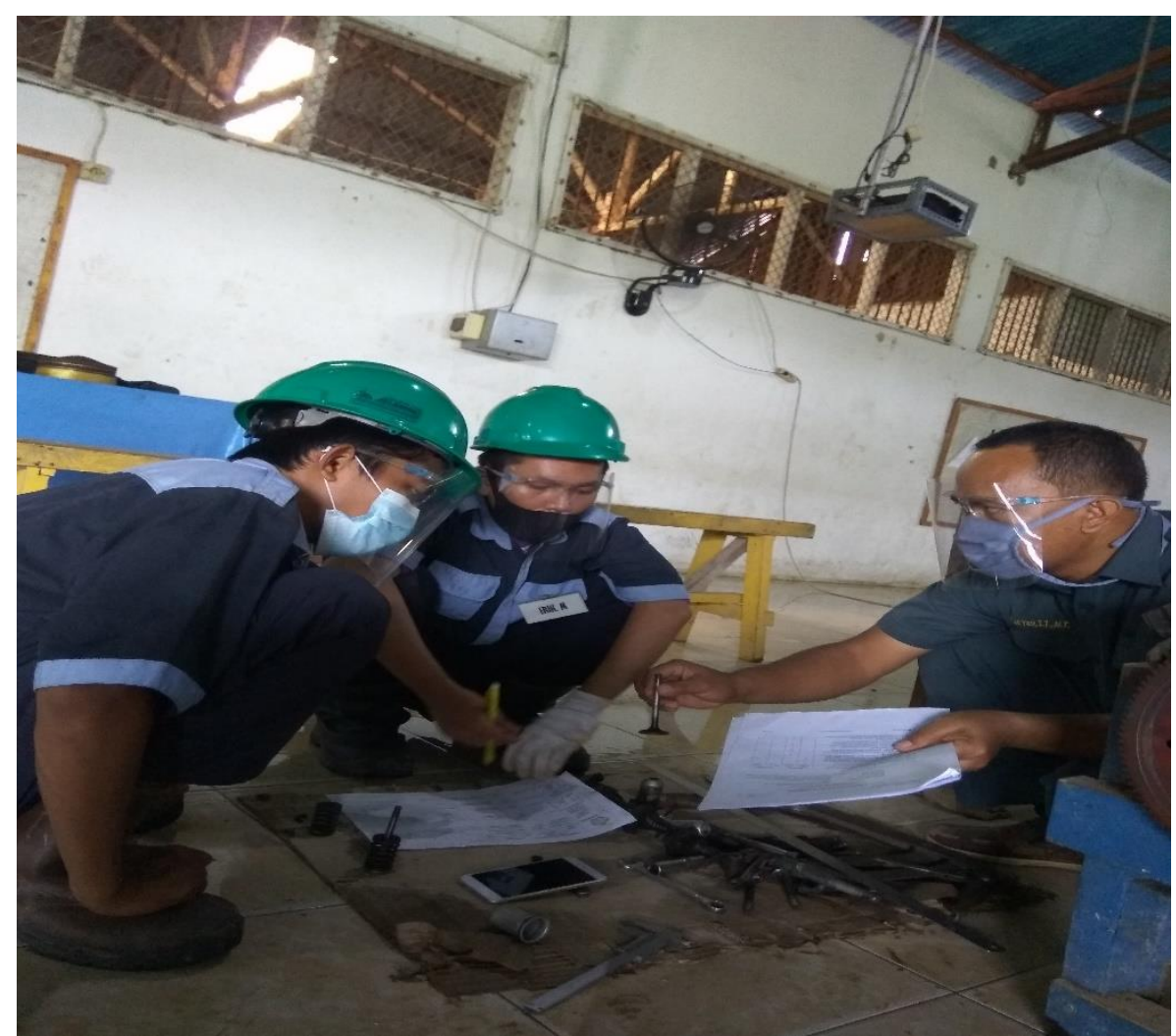

Gambar 7. Tanya jawab dengan siswa terkait nama komponen mesin

Sumber. Dokumentasi tim lapangan

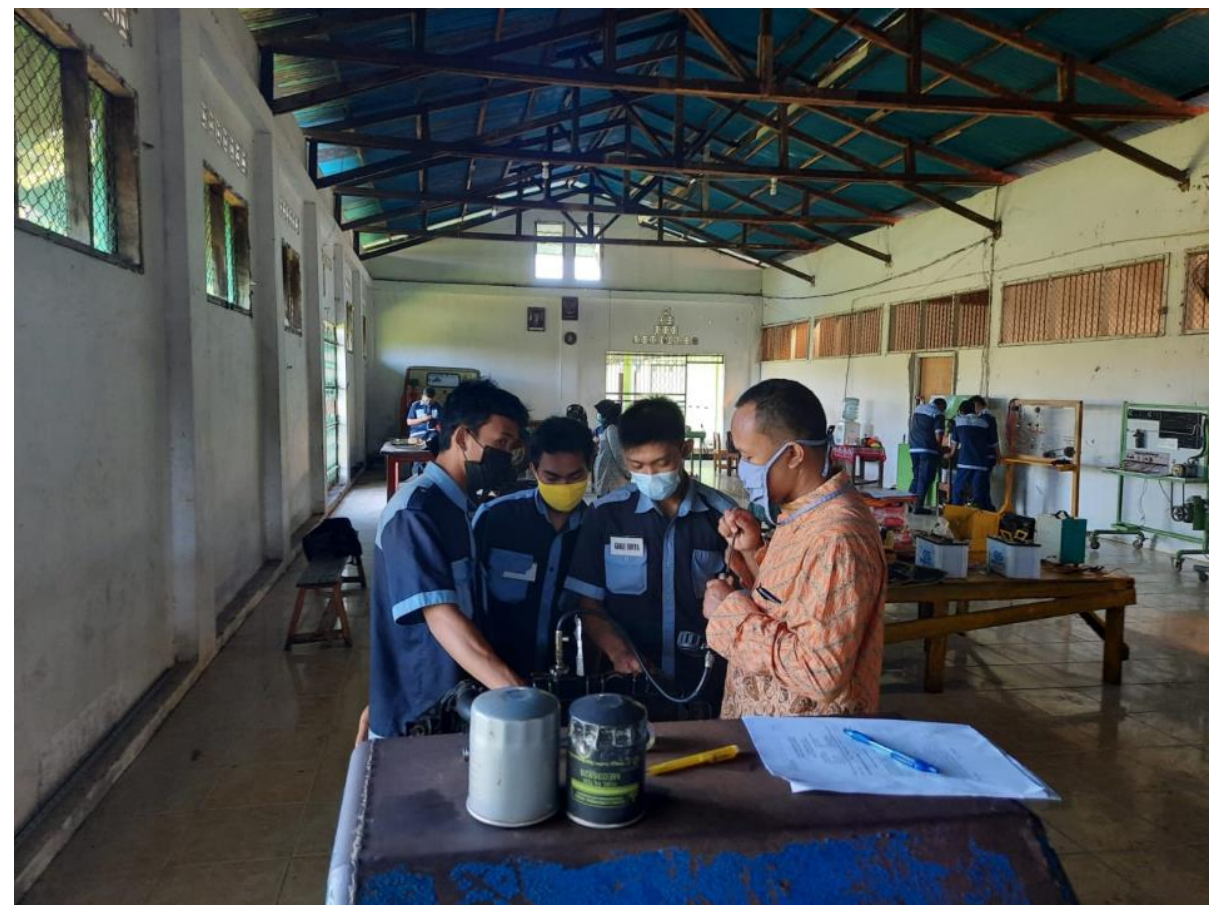

Gambar 8. Menguji siswa untuk membaca alat ukur radiator tester

Sumber. Dokumentasi tim lapangan 
PkM Uji Kompetensi Keahlian Siswa Jurusan Teknik Otomotif Alat Berat di SMK Rigomasi Bontang Ahmad Yani

Volume 1, No. 3, Desember 2021 hal. 259-272

DOI Artikel: 10.46306/jub.v1i3.49

\section{Pembahasan}

Pada penilaian aspek pengetahuan dalam pelaksanaan UKK siswa diharapkan mampu:

I. Memahami fungsi dan prinsip kerja Special tools

2. Memahami Safety di area kerja

3. Mengetahui Fungsi dan prinsip kerja system unit machine/ Engine

4. Memahami fungsi cylinder head

5. Menjelaskan cara kerja cylinder head

6. Memahami fungsi Diesel Fuel Injection Pump

7. Memahami cara kerja Diesel Fuel Injection Pump

8. Memahami fungsi komponen Radiator assy

9. Memahami cara kerja komponen Radiator assy

10. Menjelaskan perawatan machine 500 jam operasi sesuai dengan buku informasi SOP machine yang dirawat

II. Menjelaskan prosedur perawatan harian sesuai dengan buku Informasi perawatan harian model unit yang dirawat.

Penilaian aspek keterampilan dalam pelaksanaan UKK dilakukan beberapa tahap diantaranya:

I. Persiapan

a. Menyiapkan perlengkapan keselamatan kerja dan Alat Pelindung Diri

Kriteria unjuk kerja yang dinilai:

I. Persiapan alat perlengkapan keselamatan kerja dan APD sesuai dengan fungsinya

2. Penggunaan alat perlengkapan keselamatan kerja dan APD sesuai dengan fungsinya

3. Pemeliharaan alat perlengkapan keselamatan kerja dan APD sesuai dengan SOP

4. Peyimpanan alat perlengkapan keselamatan kerja dan APD sesuai dengan SOP

b. Mempersiapkan alat yang diperlukan

Kriteria unjuk kerja yang dinilai:

I. Peralatan disiapkan sesuai dengan kebutuhan

2. Penggunaan peralatan sesuai dengan fungsinya

3. Kebersihan peralatan dan tempat alat terjaga.

4. Penempatan peralatan sesuai dengan tempatnya

c. Mencari data dari service manual

Kriteria unjuk kerja yang dinilai:

I. Service Manual dipersiapkan sesuai dengan kebutuhan praktik

2. Service Manual dipergunakan sesuai dengan kebutuhan praktik

3. Data yang diperoleh dari service manual dicatat dan ditulis sesuai dengan kebutuhan praktek

4. Service Manual diperguanakan dan dipelihara dengan baik. 
PkM Uji Kompetensi Keahlian Siswa Jurusan Teknik Otomotif Alat Berat di SMK Rigomasi Bontang Ahmad Yani

Volume 1, No. 3, Desember 2021 hal. 259-272

DOI Artikel: 10.46306/jub.v1i3.49

d. Melakukan pemeriksaan awal

Kriteria unjuk kerja yang dinilai:

I. Pemeriksaan keliling unit sebelum engine start sesuai dengan SOP

2. Pemeriksaan tempat kerja sebelum perawatan sesuai dengan SOP

3. Pemeriksaan kelengkapan peralatan yang dibutuhkan sesuai SOP

4. Pemeriksaan kelengkapan K3 sesuai dengan SOP

2. Pelaksanaan

a. Melepas dan Memasang Cylinder Head Group

Kriteria unjuk kerja yang dinilai:

I. Pelepasan dan memasang Cylinder Head Group sesuai dengan SOP

2. Pembongkaran dan pembersihan komponen Cylinder Head Group sesuai dengan SOP

3. Pemeriksaan komponen Cylinder Head Group secara visual sesuai dengan SOP

4. Pengukuran komponen Cylinder Head Group sesuai dengan SOP

b. Melepas dan Memasang Fuel Injection Pump

Kriteria unjuk kerja yang dinilai:

I. Pelepasan dan memasang Fuel Injection Pump sesuai dengan SOP

2. Pembongkaran dan pembersihan komponen Fuel Injection Pump sesuai dengan SOP

3. Pemeriksaan komponen Fuel Injection Pump secara visual sesuai dengan SOP

4. Pengukuran komponen Fuel Injection Pump sesuai dengan SOP

c. Melepas dan Memasang Radiator Assy

Kriteria unjuk kerja yang dinilai:

I. Pelepasan dan memasang Radiator Assy sesuai dengan SOP

2. Pembongkaran dan pembersihan komponen Radiator Assy sesuai dengan SOP

3. Pemeriksaan komponen Radiator Assy secara visual sesuai dengan SOP

4. Pengukuran komponen Radiator Assy sesuai dengan SOP

d. Melepas dan Memasang Engine

Kriteria unjuk kerja yang dinilai:

I. Pelepasan dan memasang Engine sesuai dengan SOP

2. Pembongkaran dan pembersihan komponen Engine sesuai dengan SOP

3. Pemeriksaan komponen Engine secara visual sesuai dengan SOP

4. Pengukuran komponen Engine sesuai dengan SOP

e. Melepas dan Memasang Engine Brake

Kriteria unjuk kerja yang dinilai:

I. Pelepasan dan memasang Engine Brake sesuai dengan SOP

2. Pembongkaran dan pembersihan komponen Engine Brake sesuai dengan SOP 
PkM Uji Kompetensi Keahlian Siswa Jurusan Teknik Otomotif Alat Berat di SMK Rigomasi Bontang Ahmad Yani

Volume 1, No. 3, Desember 2021 hal. 259-272

DOI Artikel: 10.46306/jub.v1i3.49

3. Pemeriksaan komponen Engine Brake secara visual sesuai dengan SOP

4. Pengukuran komponen Engine Brake sesuai dengan SOP

f. Merawat Unit Machine 500 Jam Operasi

Kriteria unjuk kerja yang dinilai:

I. Perawatan Unit Machine 500 Jam Operasi sesuai dengan SOP

2. Pemeriksaan Unit Machine 500 Jam Operasi sesuai SOP

3. Pemeriksaan Unit Machine 500 Jam Operasi sesuai SOP

4. Penggatian engine oli dan filter oil sesuai SOP

g. Merawat Unit/Machine Harian/Daily Check

Kriteria unjuk kerja yang dinilai:

I. Perawatan Unit/Machine Harian/Daily Check sesuai dengan SOP

2. Pemeriksaan Unit/Machine Harian/Daily Check sesuai SOP

3. Pemeriksaan Unit/Machine Harian/Daily Check sesuai SOP

4. Penggatian Unit/Machine Harian/Daily Check sesuai SOP

3. Hasil Pelaksanaan

a. Hasil Melepas dan Memasang Cylinder Head Group

Kriteria unjuk hasil yang dinilai:

I. Pelepasan Cylinder Head Group tidak terjadi kerusakan pada komponen komponennya

2. Pemeriksaan Cylinder Head Group dengan benar

3. Pengukuran komponen Cylinder Head Group sesuai dengan spesikasi

4. Pemasangan Cylinder Head Group dan berfungsi dengan baik

b. Hasil Melepas dan Memasang Fuel Injection Pump

Kriteria unjuk hasil yang dinilai:

I. Pelepasan Fuel Injection Pump tidak terjadi kerusakan pada komponen komponennya

2. Pemeriksaan Fuel Injection Pump dengan benar

3. Pengukuran komponen Fuel Injection Pump sesuai dengan spesikasi

4. Pemasangan Fuel Injection Pump dan berfungsi dengan baik

c. Hasil Melepas dan Memasang Radiator Assy

Kriteria unjuk hasil yang dinilai:

I. Pelepasan Radiator Assy tidak terjadi kerusakan pada komponen komponennya

2. Pemeriksaan Radiator Assy dengan benar

3. Pengukuran komponen Radiator Assy sesuai dengan spesikasi

4. Pemasangan Radiator Assy dan berfungsi dengan baik

d. Hasil Melepas dan Memasang Engine

Kriteria unjuk hasil yang dinilai: 
PkM Uji Kompetensi Keahlian Siswa Jurusan Teknik Otomotif Alat Berat di SMK Rigomasi Bontang Ahmad Yani

Volume 1, No. 3, Desember 2021 hal. 259-272

DOI Artikel: 10.46306/jub.v1i3.49

I. Pelepasan Engine tidak terjadi kerusakan pada komponen komponennya

2. Pemeriksaan Engine dengan benar

3. Pengukuran komponen Engine sesuai dengan spesikasi

4. Pemasangan Engine dan berfungsi dengan baik

e. Hasil Melepas dan Memasang Engine Brake

Kriteria unjuk hasil yang dinilai:

I. Pelepasan Engine Brake tidak terjadi kerusakan pada komponen komponennya

2. Pemeriksaan Engine Brake dengan benar

3. Pengukuran komponen Engine Brake sesuai dengan spesikasi

4. Pemasangan Engine Brake dan berfungsi dengan baik

f. Hasil Merawat Unit Machine 500 Jam Operasi

Kriteria unjuk hasil yang dinilai:

I. Perawatan Machine 500 Jam Operasi dilakukan dengan mengacu pada service manual

2. Perawatan Machine 500 Jam Operasi yang dilakukan tanpa merusak komponen lainnya

3. Peralatan perawatan Machine 500 Jam Operasi yang digunakan tetap lengkap dan baik

4. Machine 500 Jam Operasi dapat berfungsi dengan normal

g. Hasil Merawat Unit/Machine Harian/Daily Check

Kriteria unjuk hasil yang dinilai:

I. Perawatan Unit/Machine Harian/Daily Check (On Road dilakukan dengan mengacu pada service manual

2. Perawatan Unit/Machine Harian/Daily Check (On Road yang dilakukan tanpa merusak komponen lainnya

3. Peralatan perawatan Unit/Machine Harian/Daily Check (On Road yang digunakan tetap lengkap dan baik

4. Unit/Machine Harian/Daily Check (On Road dapat berfungsi dengan normal

Berdasarkan hasil penilaian aspek pegetahuan dan penilaian aspek keterampilan dalam pelaksanaan UKK Tahun Pelajaran 2020/2021, maka hasil akhir uji kompetensi bidang keahlian teknik otomotik alat berat di SMK Rigomasi secara umum dapat mengerjakan tugas dengan baik yang diberikan dalam uji kompetensi dengan nilai rata-rata 87 yang diperoleh siswa SMK Rigomasi, berdasarkan range nilai dari pedoman UKK yang dirbitkan oleh KEMDIKBUD Tahun Pelajaran 2020/202I bahwa siswa dikatakan kompeten apabila nilainya 80-90. Artinya siswa SMK Rigomasi yang mengikuti pelaksanaan UKK dinyatakan berkompeten sesuai kompetensi keahlian jurusan teknik otomatif alat berat. 
PkM Uji Kompetensi Keahlian Siswa Jurusan Teknik Otomotif Alat Berat di SMK Rigomasi Bontang

Ahmad Yani

Volume 1, No. 3, Desember 2021 hal. 259-272

DOI Artikel: 10.46306/jub.v1i3.49

\section{KESIMPULAN DAN SARAN}

\section{Kesimpulan}

Pelaksanaan kegiatan Pengabdian kepada Masyarakat (PkM) berupa uji kompetensi bidang keahlian teknik otomotik alat berat telah dilaksanakan dengan baik dikarenakan koordinasi yang baik antara pihak SMK Rigomasi dengan STTI Bontang dalam penyelenggaraan kegiatan uji kompetensi sehingga kegiatan uji kompetensi berjalan dengan lancar dan sesuai harapan. Hasil UKK Siswa SMK Rigomasi secara umum dapat mengerjakan tugas yang diberikan dalam uji kompetensi dengan baik dengan nilai rata-rata 87 yang diperoleh siswa SMK Rigomasi, berdasarkan range nilai dari pedoman UKK Tahun Pelajaran 2020/202I siswa dikatakan kompeten apabila nilainya 80-90. Artinya siswa SMK Rigomasi yang mengikuti pelaksanaan UKK dinyatakan berkompeten sesuai kompetensi keahlian jurusan teknik otomatif alat berat.

\section{Saran}

Sebelum pelaksanaan UKK tahun berikutnya sebaiknya guru sebagai asesor internal melakukan kegiatan pelatihan Pra UKK untuk melatih siswa supaya lebih matang dalam memahami materi yang diujikan pada kegiatan UKK dan mengundang asesor eksternal untuk melatih siswa sesuai juknis pelaksaan UKK.

\section{UCAPAN TERIMA KASIH}

Terima kasih diucapkan pada seluruh pihak SMK RIGOMASI Bontang yang telah mempercayakan Dosen STTI Bontang untuk menjadi asessor eksternal uji kompetenti keahlian dan terima kasih juga atas dukungan LPPM STTI Bontang dalam melaksanakan program ini.

\section{DAFTAR PUSTAKA}

Direktorat Pembinaan SMK. 2017. PEDOMAN PENYELENGGARAAN UJI KOMPETENSI KEAHLIAN TAHUN 2020/202I. Jakarta: Kementerian Pendidikan dan Kebudayaan.

Irwanti, Y. Dwi. (20I4). EVALUASI UJI KOMPETENSI SISWA KEAHLIAN MULTIMEDIA DI SMK SE KOTA YOGYAKARTA. Jurnal pendidikan Vokasi. 4(3), 420-432

Hamidah, Okkita Rizan, Sujono, Harrizki Arie Pradana. (2021). PEMBEKALAN KOMPETENSI SISWA MENGIKUTI UJI KOMPETENSI BIDANG MULTIMEDIA BAGI SISWA SMKN I PAYUNG. ADMA Jurnal Pengabdian dan Pemberdayaan Masyarakat. 2(I), II-I8.

Purnama, M. A., \& , Fischa A, z. M. S. (2020). PELATIHAN EFIKASI DIRI TERHADAP PENURUNAN KECEMASAN SISWA - SISWI SMK KESEHATAN BINA PRESTASI TANGERANG DALAM MENGHADAPI UJIAN KOMPETENSI KEJURUAN. Jurnal Antara Keperawatan, 3(2), 66-7I.

Putri, F.A, Yoto, \& Sunarto, Y. (20I7). STUDI PENGELOLAAN PELAKSANAAN UJI KOMPETENSI KEAHLIAN DI SMK PGRI 3 MALANG. Jurnal Pendidikan Profesional, 6 (2), 19I-203.

Putra, Y. K., Sadali, M., Fathurrahman, F., \& Mahpuz, M. (2020). PELATIHAN UJI KOMPETENSI KEAHLIAN SISWA SEKOLAH KEJURUAN MENGGUNAKAN METODE PARTICIPATORY LEARNING AND ACTION (PLA). Absyara: Jurnal Pengabdian Pada Masyarakat, I (2), 80-86

Ratnawati. (202I). PENGABDIAN MASYARAKAT III KOMPETENSI SISWA-SISWI BIDANG TEKNIK KENDARAAN RINGAN DI SMK RIGOMASI BONTANG. Jurnal Pengabdian Ahmad Yani (JPAY), I(I), 34-4I

Saptono, Arcelinus, P., Waliulu, R. F., \& Mandela, W. (2020). PELATIHAN SISWA UNTUK MENGHADAPI UJIAN KOMPETENSI. Jurnal Pengabdian Aedificate, I(2), 37-4I. 
Suratno, Agus. (2016). PENGEMBANGAN INSTRUMEN PENILAIAN KOMPETENSI PRAKTIKUM ENGINE SISWA SMK PROGRAM KEAHLIAN TEKNIK OTOMOTIF. VANOS journal of Mechanical Engineering Education, I (I), I-II.

Wagiran. (20II). CLASSROOM ASSESSMENT: BAGIAN INTEGRAL PROSES PEMBELAJARAN KEJURUAN DALAM UPAYA MENYIAPKAN TENAGA KERJA SECARA HOLISTIK. INVOTEC, $7(2), 199-217$.

Yani. A., Anoi. Y.H., \& Hamdani. W. (2020). PELATIHAN PENINGKATAN KOMPETENSI PRA UJI KOMPETENSI KEJURUAN (UKK) JURUSAN TEKNIK OTOMOTIF KEPADA SISWA SMK RIGOMASI BONTANG. Jurnal Abdimas Bina Bangsa (JABB). I(I), I28-I36.

Yani, A., Ratnawati, R., \& Moch. Yusuf, M. (2020). PELATIHAN PENGGUNAAN SOFTWARE AUTOCAD UNTUK MENINGKATAN KOMPETENSI SISWA-SISWI SMK RIGOMASI BONTANG. BERDAYA: Jurnal Pendidikan Dan Pengabdian Kepada Masyarakat, 2(2), 6I-68.

Yani. A, Irhamni, Septiani. M, Fitria, Irianto, \& Ratnawati. (202I). PENYULUHAN DAN PELATIHAN PENGOLAHAN LIMBAH PLASTIK MENJADI BAHAN BAKAR MINYAK UNTUK MENGATASI SAMPAH PLASTIK DI KOTA BONTANG. Jurnal Pengabdian Ahmad Yani (JPAY), I (I), I-8 